\title{
The community of Diptera (Insecta) colonizing axils of Alocasia macrorrhizos (L.) G.Don (Araceae), with records of Aedes aegypti (L.) and Aedes albopictus (Skuse) in urban areas of Manaus, Amazonas
}

\author{
Ruth Leila Ferreira-Keppler ${ }^{* 1}$, Ulisses Gaspar Neiss ${ }^{2}$, Sharlene Roberta da Silva Torreias ${ }^{1}$ \& \\ Claudimir Menezes Campos ${ }^{1}$ \\ Instituto Nacional de Pesquisas da Amazônia, Coordenação de Biodiversidade, Manaus, AM, Brazil \\ ${ }^{2}$ Departamento de Polícia Técnico-Cientifica, Instituto de Criminalística, Manaus, AM, Brazil \\ *Corresponding author: Ruth Leila Ferreira-Keppler, e-mail: ruth@inpa.gov.br
}

FERREIRA-KEPPLER, R. L., NEISS, U. G., TORREIAS, S. R. da S., CAMPOS, C. M. The community of Diptera (Insecta) colonizing axils of Alocasia macrorrhizos (L.) G.Don (Araceae), with records of Aedes aegypti (L.) and Aedes albopictus (Skuse) in urban areas of Manaus, Amazonas. Biota Neotropica. 17(3): e20160291. http://dx.doi.org/10.1590/1676-0611-BN-2016-0291

\begin{abstract}
Alocasia macrorrhizos (L.) G.Don grows and proliferates in shaded areas in several forest fragments in urban zones. The adult plant has axils that accumulate rain water (phytotelmata) and serve as breeding sites for several families of aquatic insects. The objective of this study was to determine the composition of the entomofauna associated with water accumulations in axils of A. macrorrhizos in urban areas of Manaus, Brazil. Individuals of A. macrorrhizos were sampled in five forest fragments, between April/2005 and March/2007 in urban areas of Manaus, totaling 184 sampling units. A manual suction hose was used for the removal of entomofauna. A total of 1,941 immatures of Diptera were collected representing the following families: Culicidae (96.5\%), Chironomidae (2\%), Psychodidae (0.7\%), Ephydridae $(0.7 \%)$ and Corethrellidae (0.1\%). Five Culicidae species were identified: Wyeomyia melanocephala Dyar \& Knab, 1906 (91.7\%), Wy. ypsipola Dyar, 1922 (4.3\%), Aedes albopictus (Skuse, 1894) (2.3\%), Ae. aegypti (Linnaeus, 1762) (1.5\%) and Johnbelkinia longipes (Fabricius, 1805) (0.1\%). The members of Culicidae were the most abundant, confirming the importance of this group in communities associated with phytotelmata, with a positive relation to the volume of water $(\mathrm{p}<0.05)$. The occurrence of Ae. aegypti and Ae. albopictus in axils of A. macrorrhizos demonstrates the potential of this Araceae as a breeding site of these medically important species. However, the real contribution of this Araceae in the maintenance and dispersion of populations of these two species of mosquitoes throughout the year should be further studied.
\end{abstract}

Keywords: Culicidae, forest fragments, mosquitoes, phytotelmata, vectors

\section{Comunidade de Diptera (Insecta) colonizando axilas de Alocasia macrorrhizos (L.) G.Don (Araceae), com registros de Aedes aegypti (L.) e Aedes albopictus (Skuse) na área urbana de Manaus, Amazonas}

\begin{abstract}
Resumo: A. macrorrhizos (Araceae) é cultivada e se prolifera naturalmente em locais sombreados em diversos fragmentos de mata na zona urbana de Manaus. A planta adulta apresenta axilas que acumulam água da chuva (phytotelmata) e servem de criadouro para diversas famílias de insetos aquáticos. O objetivo do trabalho foi conhecer a composição da entomofauna associada às axilas de A. macrorrhizos, na área urbana de Manaus, Amazonas, Brasil. Entre 2005 e 2007, indivíduos de $A$. macrorrhizos foram amostrados em cinco fragmentos urbanos de mata, totalizando 184 unidades amostrais. Uma mangueira de sucção manual foi utilizada para coletar a fauna associada. Um total de 1.941 imaturos de Diptera foram coletadas, representadas pelas seguintes famílias: Culicidae (96,5\%), Chironomidae (2\%), Psychodidae (0,7\%), Ephydridae $(0,7 \%)$ e Corethrellidae $(0,1 \%)$. Foram identificadas cinco espécies de Culicidae: Wyeomyia melanocephala Dyar \& Knab, 1906 (91,7\%), Wy. ypsipola Dyar, 1922 (4,3\%), Aedes albopictus (Skuse, 1894) (2,3\%), Ae. aegypti (Linnaeus, 1762) (1,5\%) e Johnbelkinia longipes (Fabricius, 1805) (0,1\%). Os representantes de Culicidae foram os mais abundantes confirmando a importância desse grupo nas comunidades associadas a fitotelmatas, com relação positiva com o volume de água por planta $(\mathrm{p}<0.05)$. A ocorrência de Ae. aegypti e Ae. albopictus nas axilas de A. macrorrhizos demonstra o potencial dessa Araceae como criadouro para estas espécies de importância médica. Contudo, a real contribuição dessa Araceae na manutenção e dispersão populacional dessas duas espécies de mosquitos ao longo do ano precisa ser melhor estudada.
\end{abstract}

Palavras-chave: Culicidae, fitotelmata, fragmentos florestais, mosquitos, vetores. 


\section{Introduction}

Plant structures capable of storing rain water, such as modified leaves, stem holes, leaf axils, flowers, open fruits and fallen leaves are known by the term phytotelmata (Fish 1983). Among the best-known phytotelmata are the axils of plants. Plants with these structures that occur in South America include: Phenakospermum Endl. ("bananeira-brava": Strelitziaceae), Musa L. (Musaceae), Bambusa Schreb. (Poaceae), Mauritia L. (Arecaceae), Heliconia L. (Heliconiaceae), Calathea G. Mey. (Maranthaceae), Guzmania Ruiz \& Pavón and Vriesea Lindl. (Bromeliaceae), Alocasia (Schott) G. Don (Araceae) (Kitching 2000) and Eryngium (Apiaceae) (Campos 2010). Some of these plants have been used as ornaments, such as giant taro or "tajá" (Araceae), a plant from Asia that is well distributed through Venezuela, Colombia and Brazil. In Brazil, 12 genera and 55 species of Araceae are known in Reserva Florestal Ducke, which is adjacent to the city of Manaus (Ribeiro et al. 1999).

The fauna associated with phytotelmata is mainly composed of insects, with more than 70 families and 11 orders recorded so far, with Diptera as the most abundant order (Greeney 2001). In these environments aquatic larvae of Diptera are considered to be an ecologically important group because it occupies several aquatic ecosystems and contributes to the diet of other animals in these environments (Kitching 2000, 2001).

Many families of Diptera have medical or veterinary importance because they are involved in the transmission of etiological agent. The habitats of the immature forms of Culicidae have therefore received attention. Ecological and epidemiological studies show the increasing number of recipients in urban areas as a result of waste discarded by modern society (Soares et al. 2008). Consequently, providing sites for mosquitoes of Aedes (Stegomyia) Theobald, in urban areas (Cunha et al. 2002), being responsible for transmitting dengue, Chikungunya, zika virus and yellow fever throughout the Americas, Africa and Asia (Marcondes \& Ximenes 2016, Lopes et al. 2014).

The capacity of Araceae (genera Alocasia, Colocasia and Xanthosoma) to hold immature forms of aquatic insects, mainly Diptera, in the water stored in their axils has been studied in forest areas in Venezuela (Delgado \& Machado-Allison 2006). Members of Sabethini (Culicidae) were the most frequent and abundant (Machado-Allison et al. 1986, Delgado \& Machado-Allison 2006). Some species have the capacity to detect favorable habitats for oviposition, with varying degrees of specificity as to the host plant, and this can be specific to only one plant or to several plant species with similar structures within a specific area (Kitching 2000). We also need to consider that the axil size, volume of water, number of leaves, and quantity of debris are all variables that influence the structure of the communities associated with phytotelmata (Ambruster et al. 2002 Melnychuk \& Srivastava 2002, Ospina-Bautista et al. 2004, Torreias et al. 2010).

Forest fragments in urban or suburban areas of Manaus offer favorable places for the development of several insect species in public and private areas. These environments, if not monitored, may become locations used by city residents for disposal of artificial recipients - the main breeding sites of Aedes aegypti (L., 1762) (Lopes et al. 1985, Consoli \& Lourenço-de-Oliveira 1994). In addition, many of these fragments have secondary forest, where populations of Alocasia macrorrhizos (L.) G.Don are abundant and grow naturally in these uninhabited areas (personal observations).

The objective of the present study was to determine the composition of entomofauna associated with the axils of $A$. macrorrhizos and to verify the potential of this species of ornamental plant as a breeding site for Ae aegypti and Ae. albopictus (Skuse, 1894) in urban zones of Manaus, Brazil.

\section{Material and Methods}

Samples were collected in urban areas of the municipality of Manaus, Amazonas state. The region in which the city is located has two seasons during the year: the rainy season (December to May) being March the rainiest month, and the dry season (June to November) being August the driest month (Fisch et al. 1998). Alocasia macrorrhizos (Figure 1a) is grown and proliferates naturally in shaded areas, mainly on wet and acidic soils. The adult plant has leaves up to one-meter long, thus having large leaf axils that can store a significant quantity of water (Gómez Zuluaga 2003).

Sampling was done where more individuals of $A$. macrorrhizos were available, in five forest fragments: Area 1: Campus I of the Instituto Nacional de Pesquisas da Amazônia / INPA (03 05' 46.97' S, 59 59' 23.58” W), Area 2: Paraiba Street $\left(03^{\circ} 05^{\prime} 31.92^{\prime}\right.$ S, $\left.60^{\circ} 00^{\prime} 30.19^{\prime \prime} \mathrm{W}\right)$, Area 3: Parque Municipal do Mindu (03 $04^{\circ}$ '41.6" S, 60 00' 29.5" W), Area 4: Franceses Road (03 04' 25" S, 60 02' 10" W), Area 5: Passeio do Mindu $\left(03^{\circ} 05^{\prime} 12.4^{\prime \prime} \mathrm{S}, 60^{\circ} 00^{\prime} 33^{\prime \prime} \mathrm{W}\right)$.

Areas 1 and 3 have plant species that are characteristic of primary forest that survived cutting mainly due to resprouting from the original stem, as well as species introduced by gardening. These areas make a major contribution to the conservation of the natural and cultural resources in Manaus municipality. By contrast, forest fragments in Areas 2, 4 and 5 are characterized by heavy anthropic intervention, with pioneer species characteristic of secondary vegetation. These areas have rainwater retained in permanently waterlogged soil, favoring the development of palms, "bananeira-brava" and large individuals of giant taro (more than $1 \mathrm{~m}$ in height).
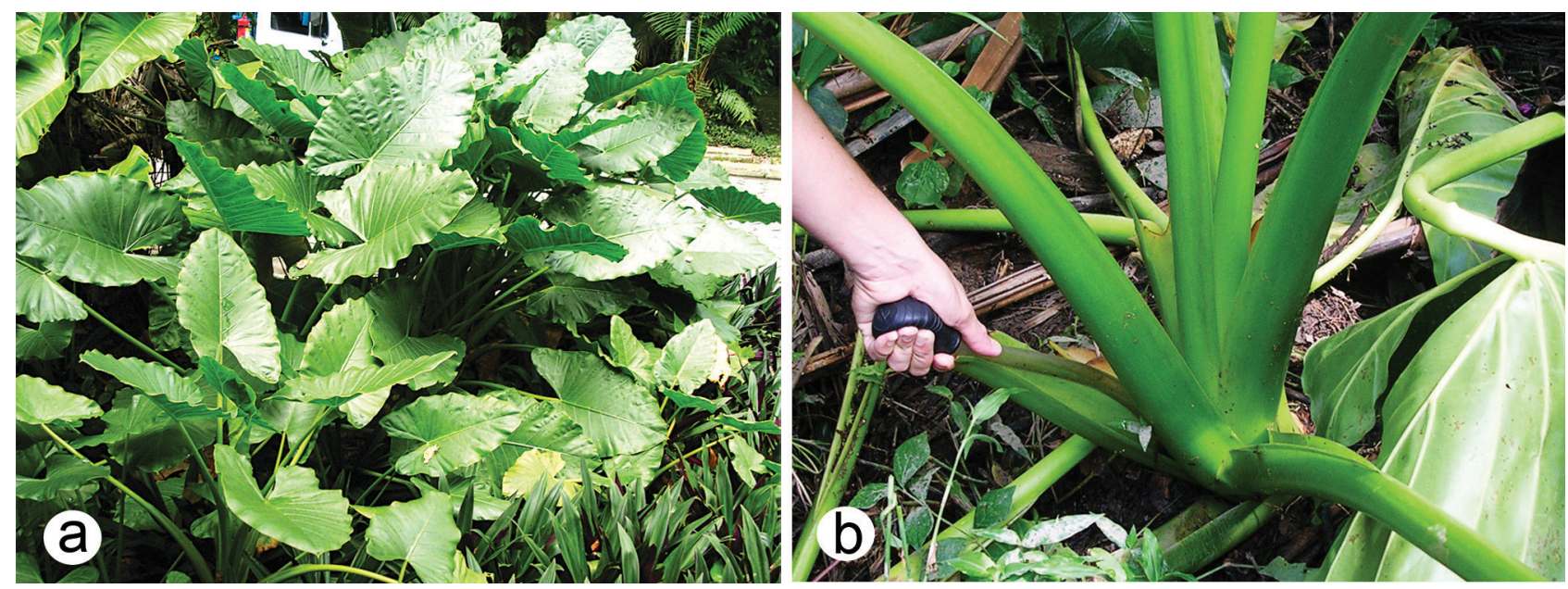

Figure 1. a) Group of A. macrorrhizos, located at INPA Campus I, Manaus, AM; b) Manual suction hose used to collect aquatic entomofauna. 
Campus I of INPA (Area 1) and Parque do Mindu (Area 3) were considered to be the sites with the lowest anthropic impact because, despite having masonry constructions, they had a broad cover of primary vegetation and ornamental plants. Area 2 (Paraiba Street) was considered to be the most impacted because it has lowland vegetation that is exposed to sewage disposal and the waste dumping. Areas 4 and 5 have secondary vegetation fragments of approximately 1 ha each and low canopy vegetation, which partially covers Araceae plants. These are found grouped on sites covered by Selaginella (Pteridophyta).

Sampling periods corresponded to transition months between wet and dry periods in the hydrological regime: April to July 2005, January to August 2006, and March 2007, for a total of 13 months. A manual suction hose was used for the removal of the entomofauna (Figure 1b) and all of the liquid content was transferred to plastic $500 \mathrm{~mL}$ recipients. To ensure the removal of any specimens from the bootom, a second wash was performed on each leaf axil, with distilled water, and the liquid deposited in another container properly labeled. All material was transported to the Laboratório de Insetos Aquáticos da Coordenação de Biodiversidade (CBio/INPA). Fourth-instar larvae and pupae of Culicidae were individualized to obtain adults and to help in species-level identification (Lane 1953a, b, Motta \& Lourenço-de-Oliveira 2000). The remaining samples were fixed in $80 \%$ ethanol for identification at the family level. Mosquito genera were abbreviated according to Reinert (2009). The positivity index for each species of Culicidae was estimated by dividing the number of positive sampled axils for a given species by the total A. macrorrhizos axils investigated (Gomes 1998). The positivity index is usually used in studies with Culicidae and is important because it reveals the percentage frequency of occurrence of a particular species on the sampled sites throughout the investigated period (Resende et al. 2013).

In order to characterize the phytotelmata environment, we measured $\mathrm{pH}$ with a Warterproof PC 300, Oakton Instruments and the volume of water retained in A. macrorrhizos axils using a graduated cylinder. Such parameters were selected for having influence phytotelmata communities structuring (Yanoviak 1999, Kitching 2001). Simple linear regression $(\operatorname{Ln}(x+1))$ was used to evaluate relationships between total mosquito abundance and the total amount of water $(\mathrm{mL})$, and also between total mosquito abundance and $\mathrm{pH}$ values (significance level, $\mathrm{p}<0.05$ ) (Zar 1996). The collected material is deposited in the Coleção de Invertebrados do Instituto Nacional de Pesquisas da Amazônia - INPA, Manaus, Brazil.

\section{Results}

A total of 1,941 immatures of Diptera were collected in 184 sampling units. As expected in communities of phytotelmata, the members of family Culicidae were the most abundant, being $96.5 \%$ of all individuals, followed by Chironomidae (2\%), Psychodidae (0.7\%), Ephydridae $(0.7 \%)$ and Corethrellidae ( $0.1 \%$ ) (Table 1 and 2$)$. Of the total of 184 samples analyzed, 147 had immature insect in their axils, with an average of $10.5(\mathrm{SE}=16.8)$ individuals per plant.

Wyeomyia melanocephala Dyar \& Knab, 1906 was the most abundant species (91.7\%), followed by Wy. ypsipola Dyar, 1922 (4.3\%) (Table 2). These species occurred in all of the sampling sites. They had high rates of positivity index ( $78.3 \%$ and $24.5 \%$, respectively). Johnbelkinia longipes (Fabricius, 1805), a wild mosquito, was found in only one sample (Table 2). Immatures of Ae. albopictus and Ae. aegypti was found in four areas with low abundance (Table 2) and low index of positivity (Table 3 ).

The volume of water in the plants ranged from a minimum of 10 to a maximum of $210 \mathrm{~mL}$ (average of $40 \mathrm{~mL}$ ), and the abundance of Culicidae larvae was positively related to the water volume $(\mathrm{p}<0.05$, Figure 2$)$. The $\mathrm{pH}$ varied from 6 to 7.2, and did not influence the abundance of mosquitoes $\left(r^{2}=0.0286, y=-2.43970427+0,644322259 * x, p>0.05\right)$.

\section{Discussion}

Two Culicidae tribes were found in this study: Sabethini and Aedini. Sabethini species are known by their strong association with phytotelmata formed by the axils of plants such as bromeliads, Araceae, Rapataceae and Heliconiaceae, and also phytotelmata formed in bamboo internodes, fallen husks of fruits and fallen flower bracts of palms (Navarro et al. 2007, Kitching 2000). In these environments, females lay their eggs in isolation and larvae usually develop in confined spaces.

The two mosquito species most abundant and frequent, Wy. melanocephala and Wy. ypsipola, occurred in all of the sampling sites, with high rates of positivity index, indicating a strong affinity with the phytotelmata studied in the urban area. This corroborates the studies by Machado-Allison et al. (1986) and Delgado \& Machado-Allison (2006), who recorded these two species as being the most frequent and abundant larvae collected in A. macrorrhizos in a forest in Venezuela. In urban areas, Wy. melanocephala was also recorded colonizing Zingiberaceae axils, which have a similar

Table 1. Abundance of Diptera families collected in A. macrorrhizos $(\mathrm{n}=184)$ in urban areas of Manaus, AM, 2005 to 2007. Caption: Area 1: Campus I- INPA; Area 2: Paraiba Street; Area 3: Parque do Mindu; Area 4: "Franceses" Road; Area 5: "Passeio do Mindu".

\begin{tabular}{|c|c|c|c|c|c|c|}
\hline Families & Area 1 & Area 2 & Area 3 & Area 4 & Area 5 & Total \\
\hline Culicidae & 771 & 613 & 184 & 184 & 121 & 1,873 \\
\hline Chironomidae & 0 & 40 & 0 & 0 & 0 & 40 \\
\hline Psychodidae & 0 & 8 & 0 & 4 & 1 & 13 \\
\hline Ephydridae & 10 & 1 & 1 & 0 & 1 & 13 \\
\hline Corethrellidae & 0 & 2 & 0 & 0 & 0 & 2 \\
\hline Total & 781 & 664 & 185 & 188 & 123 & 1,941 \\
\hline
\end{tabular}

Table 2. Abundances and percentages of total (\%) of Culicidae species collected in A. macrorrhizos ( $\mathrm{n}=184)$ in urban areas of Manaus, AM, 2005 to 2007. Area 1: Campus I/INPA; Area 2: Paraiba Street; Area 3: Parque do Mindu; Area 4: "Franceses" Road; Area 5: "Passeio do Mindu".

\begin{tabular}{|c|c|c|c|c|c|c|}
\hline Species & Area $1(\%)$ & Area $2(\%)$ & Area $3(\%)$ & Area $4(\%)$ & Area $5(\%)$ & Total (\%) \\
\hline Wy. melanocephala & $696(37.2)$ & $557(29.7)$ & $174(9.3)$ & $172(9.2)$ & $118(6.3)$ & $1,717(91.7)$ \\
\hline Wy. ypsipola & $54(2.9)$ & $8(0.4)$ & $5(0.3)$ & $10(0.5)$ & $3(0.2)$ & $80(4.3)$ \\
\hline Ae. albopictus & $14(0.7)$ & $27(1.4)$ & $1(0.1)$ & $2(0.1)$ & 0 & $44(2.3)$ \\
\hline Ae. aegypti & $7(0.4)$ & $21(1.1)$ & $1(0.1)$ & 0 & 0 & $29(1.5)$ \\
\hline Jo. longipes & 0 & 0 & $3(0.2)$ & 0 & 0 & $3(0.2)$ \\
\hline Total & $771(41.2)$ & $613(32.7)$ & $184(9.8)$ & $184(9.8)$ & $121(6.5)$ & $1,873(100)$ \\
\hline
\end{tabular}




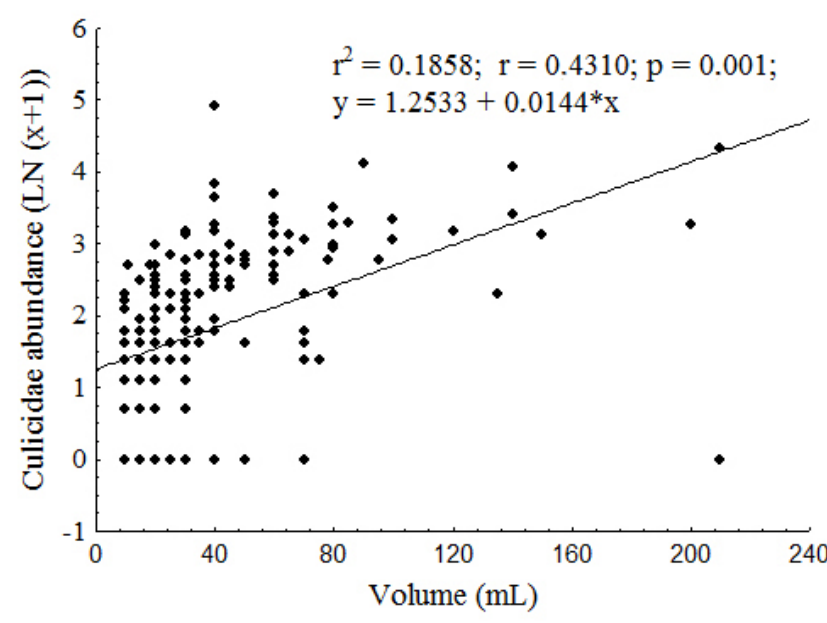

Figure 2. Simple linear regression $(\operatorname{Ln}(\mathrm{x}+1))$ of Culicidae abundance and the volume of water (mL) retained in the axils of A. macrorrhizos, Manaus, AM.

Table 3. Positivity index (frequency of occurrence) of Culicidae species collected in A. macrorrhizos ( $\mathrm{n}=184)$ in urban areas of Manaus, AM, 2005 to 2007.

\begin{tabular}{cc}
\hline Culicidae species & Positivity index \\
\hline Wy. melanocephala & 78.26 \\
Wy. ypsipola & 24.45 \\
Ae. albopictus & 8.15 \\
Ae. aegypti & 6.52 \\
Jo. longipes & 0.54 \\
\hline
\end{tabular}

ways of retaining water (Machado-Allison et al. 1986, Consoli \& Lourenço-de-Oliveira 1994).

Wyeomyia specimens are often found in bromeliads, bamboo internods and tree holes located in forest fragments in Brazil (Marques \& Forattini 2008, Torreias et al. 2010, Ceretti-Junior et al. 2014). It is known that adult females are eclectic in the search for hosts. However, detailed studies of feeding behavior and biology of the group are still incipient (Forattini 2002). In Brazil, the genus Wyeomyia may be involved in the natural transmission of arbovirus Ilheus, causing fever and encephalitis (Lopes et al. 2014). However, the species of this genus are not yet listed as important vectors of viral agents.

On the field, observations were made regarding the feeding habit that corroborated with the results by Machado-Allison et al. (1986): Wy. melanocephala larvae uses the siphon as a supporting organ to fix itself in the deepest part of the axil and filter organic matter particles. By contrast, Wy. ypsipola larvae stays at the bottom searching for prey (smaller larvae of Culicidae and Ephydridae, which are common in these Araceae), directing its mouth apparatus to the surface. This species has a bucal apparatus that is well developed for predatory habits; however, if prey is lacking, it can also feed on filtered organic matter (Machado-Allison et al. 1986).

We found Jo. longipes in only one sample (with three individuals) in June 2006. Anthropic alterations, including use of ornamental plants for landscaping purposes, may offer a stimulus for the presence of these species, which previously were found exclusively in wild areas (Consoli \& Lourenço-de-Oliveira 1994). Specimens of Johnbelkinia Zavortink, appear to be specific to phytotelmata formed by axils of Araceae (Navarro et al. 2007), as reported by Machado-Allison et al. (1986) and Delgado \& Machado-Allison (2006), who recorded larvae of Jo. ulopus (Dyar \& Knab) only in axils of the aroids plants Alocasia, Colocasia and Xanthosoma in Venezuela.
Regarding Aedini, we identified members of Ae. albopictus and Ae. aegypti. Immatures of Ae. albopictus and Ae. aegypti were collected in areas with low anthropic impact (Areas 1 and 3) and also in an area with high impact (Area 2), but always in shaded areas provided by well-developed leaves of large Araceae located a few meters from human constructions and residential areas. In Brazil, Ae. albopictus has been previously found in phytotelmata, such as holes in trees, bamboo internodes (Gomes et al. 1992, Muller \& Marcondes 2010) and bromeliads (Marques et al. 2001, Mocellin et al. 2009).

Ae. albopictus is only considered to be a primary vector for the spread of dengue and yellow fever in some regions of Asia; additionally, many studies show the capacity of this species to serve as a potencial vector for several arboviruses (Alencar et al. 2008), including dengue, Chikungunya and zika virus (Marcondes \& Ximenes 2016). Thus, the possibility of local transmission of all these arboviruses by this insect cannot be discarded, indicating the need for studies of their breeding sites, especially in urban areas. Aedes albopictus can easily adapt to rural areas as well as urban areas, becoming a zoonotic bridge in both places. Therefore, due to the wide ecological valence and the susceptibility of this species to the main arboviruses registered in Brazil, it is important that this mosquito is also included in epidemiological monitoring and control programs together with Ae. aegypti (Alencar et al. 2008, Marcondes \& Ximenes 2016).

Ae. aegypti is the only known vector of dengue, Chikungunya and zika virus in urban areas in many Brazilian States. The occurrence of Ae. aegypti tends to indicate a public health problem. This species has synanthropic behavior and usually occupies anthropic areas (Forattini 2002). In urban areas, it usually breeds in discarded recipients; however, studies show that this species uses natural breeding sites in urban and rural areas with a great variety of microorganisms and organic matter for the development of its immature forms, such as domesticated bromeliads whether or not they are used for decorative purposes (Cunha et al. 2002, Delgado \& Machado-Allison 2006, Gonçalves \& Messias 2008).

In the present study, Ae. aegypti and Ae. albopictus was found in low number and with sporadic nature of occurrence, as shown by the low index of positivity for both species. As demonstrated in other studies in urban areas (Mocellin et al. 2009; Santos et al. 2011), this kind of habitat (axils of plants) does not seem to play an important role as breeding site for the larvae of these mosquitoes, being the water held in manmade containers the main oviposition sites for Ae. aegypti and Ae. albopictus females (Soares et al. 2008). These two species of mosquitoes were more abundant in Areas 1 and 2, especially Area 2, considered to be the most impacted anthropically, with greater discarding of domestic waste, which may have contributed to the higher number of Ae. aegypti and Ae. albopictus in this sample site in comparison with the other sample areas. The record of these species colonizing axils of $A$. macrorrhizos is important, since this small population of mosquitoes can serve as a reservoir for the introduction of these species in nearby residences.

Other organisms were collected in the axils of A. macrorrhizos, including Chironomidae, Psychodidae, Ephydridae and Corethrellidae larvae, some of which inhabited the axils with Culicidae. These families are very common in these environments, but according to the literature they had low number of species when compared with other studies of phytotelmata in forest areas in Central Amazon (Neiss 2007, Torreias \& Ferreira-Keppler 2011).

Chironomidae were found in only one sample (Area 2). Nevertheless, after Culicidae, this is the second most abundant and diverse group in phytotelmata, colonizing various species of plants that are capable of storing water (Kitching 2000) in addition to breeding in sites formed by mycotelmata (Ferreira et al. 2001, Serpa-Filho et al. 2007). In this 
environment, chironomid larvae have broad feeding plasticity (preying, filtering-collecting, scraping and collecting).

Information on Corethrellidae is relatively scarce in the Brazilian Amazon. According to Borkent (2008) there are 12 species recorded from this area. The females of Corethrella Coquillett, the only extant genus of the family, are hematophagous, feeding exclusively on frog blood. The immature forms are generalist predators which develop in still waters, lakes, bamboo internodes and plant axils (Borkent 2008). Corethrella was collected only once in the present study. Larvae of the genus was also found in the bromeliad Guzmania brasiliensis Ule, in forest areas in the Amazon (Torreias \& Ferreira-Keppler 2011).

Ephydridae larvae were found in the axils of Araceae, usually with little water and high quantities of organic matter. These organisms are detritivorous (Delgado \& Machado-Allison 2006) and feed on fine sediments from allocthonous components that, in these locations, depend on retained rain water, leading to a diet with extrinsic characteristics. Larvae of Ephydridae has already been registered in bamboo internodes (Sanchez \& Liria 2009), and has been previously found in A. macrorrhizos, as related by Delgado \& Machado-Allison (2006). It seems that this family mainly inhabits places with plenty of organic matter where they feed on debris.

The positive relationship between immature mosquitoes and water volume, corroborate other studies on Culicidae that use phytotelmic habitats (Yanoviak 1999, Torreias et al. 2010). In A. macrorrhizos, as in other phytotelmic habitats, the increase in the volume and persistence of water are essential factors to maintain an aquatic community in these ecosystems (Srivastava \& Lawton 1998, Kitching 2000, Ospina-Bautista et al. 2004, Yanoviak et al. 1999 and 2006).

Through this study it was possible to verify the potential of A. macrorrhizos as breeding sites for Ae. aegypti and Ae. albopictus, as well as other wild Culicidae. The results show that giant taro (Araceae), commonly used as ornamental plants in urban areas of Manaus, can be used sporadically by epidemiologically important mosquitoes species. However, the real contribution of this Araceae in the maintenance and dispersion of populations of these two species of mosquitoes throughout the year should be further studied.

\section{Acknowledgments}

We thank Dr. Monique Albuquerque Motta, FIOCRUZ - RJ, for helping in the identification of genus Wyeomyia. Financial support was provided by CNPq process 480105/2007-3 and 306081/2013-0, MCTI/INPA, and FAPEAM - Fundação de Amparo à Pesquisa do Estado do Amazonas Edital 020/2013 - PAPAC. The second and fourth author thanks PCI/MCTI/INPA/CNPq for the fellowships provided.

\section{Author's Contributions}

Ruth L. Ferreira-Keppler: substantial contribution in the concept and design of the study; contribution to manuscript preparation.

Ulisses G. Neiss: contribution to data analysis and interpretation; contribution to manuscript preparation and critical revision.

Sharlene Roberta S. Torreias: contribution to data analysis and interpretation; contribution to manuscript preparation.

Claudimir M. Campos: contribution to data collection.

\section{Conflicts of Interest}

The authors declares that they have no conflict of interest related to the publication of this manuscript.

\section{References}

ALENCAR, C.H.M., ALBUQUERQUE, L.M., AQUINO, T.M.F., SOARES, C.B., RAMOS JÚNIOR, A.N., LIMA, J.W.O. \& PONTES, R.J.S. 2008. Potencialidades do Aedes albopictus como vetor de arboviroses no Brasil: um desafio para a atenção primária. Rev. APS. 11:459-467.

AMBRUSTER, P., HUTCHINSON, R.A. \& COTGREAVE, P. 2002. Factors influencing community structure in a South American tank bromeliad fauna. Oikos. 96:225-234.

BORKENT, A. 2008. The frog-biting midges of the world (Corethrellidae: Diptera). Zootaxa. 1804:1-456.

CAMPOS, R. E. 2010. Eryngium (Apiaceae) phytotelmata and their macro-invertebrate communities, including a review and bibliography. Hydrobiologia. 652:311-328.

CERETTI-JÚNIOR, W., MEDEIROS-SOUSA, A.R., MULTINI, L.C., URBINATTI, P.R., VENDRAMI, D.P., NATAL, D., MARQUES, S., FERNANDES, A., OGATA, H. \& MARRELLI, M.T. 2014. Immature mosquitoes in bamboo internodes in municipal parks, city of São Paulo, Brazil. J. Am. Mosq. Control. Assoc. 30(4):268-74.

CONSOLI, R.A.G.B. \& LOURENÇO-DE-OLIVEIRA, R. 1994. Principais Mosquitos de Importância Sanitária no Brasil. Editora FIOCRUZ, Rio de Janeiro.

CUNHA, S.P., ALVES, J.R.C., LIMA, M.M., DUARTE, J.R., BARROS, L.C.V. \& SILVA, J.L. 2002. Presença de Aedes aegypti em Bromeliaceae e depósitos com plantas no Município do Rio de Janeiro, RJ. Rev. Saúde Pública. 36:244-255.

DELGADO, L. \& MACHADO-ALLISON, C.E. 2006. La comunidad de insectos acuáticos asociados a Alocasia macrorrhiza en Venezuela. Composición de la fauna y aspectos de su historia natural. Entomotropica. 21:105-115.

FERREIRA, R.L.M., OLIVEIRA, A.F., PEREIRA, E.S. \& HAMADA, N. 2001. Occurence of larval Culicidae (Diptera) in water retained in Aquascypha hydrophora (Fungus: Stereaceae) in Central Amazonia, Brazil. Mem. Inst. Oswaldo Cruz. 96:1165-1167.

FISCH, G., MARENGO, J.A. \& NOBRE, C.A. 1998. Uma revisão geral sobre o clima da Amazônia. Acta Amazon. 28:101-126.

FISH, D. 1983. Phytotelmata: Flora and Fauna. In Phytotelmata: Terrestrial Plants as Host for Aquatic Insect Communities (J.H. Frank \& L.P. Lounibos, eds). Plexus, New Jersey, p.1-28.

FORATTINI, O.P. 2002. Culicidologia Médica. Vol. 2: Identificação, Biologia, Epidemiologia. Editora Universidade de São Paulo, São Paulo.

GOMES, A.C. 1998. Medidas dos níveis de infestação urbana por Aedes (Stegomyia) aegypti e Aedes (Stegomyia) albopictus em programas de Vigilância Entomológica. Inf. Epidemiol. SUS. 7:49-57.

GOMES, A.C., FORATTINI, O.P., KAKITANI, I., MARQUES, G.R., MARQUES, C.C. \& MARUCCI, D. 1992. Microhabitats de Aedes albopictus (Skuse) na região do Vale do Paraíba, Estado de São Paulo, Brasil. Rev. Saúde Pública. 26:108-118.

GÓMEZ ZULUAGA, M.H.G. 2003. Una revisión sobre el Bore (Alocasia macrorrhiza). In Agroforestería para la Producción Animal en América Latina - II. Memorias de la segunda conferencia electrónica (agosto de 2000 - marzo de 2001) (M.D. Sánchez \& M.R. Méndez, eds). Roma: Organización de las Naciones Unidas para la agricultura y la alimentación, p.203-212.

GONÇALVES, K.S. \& MESSIAS, M.C. 2008. Ocorrência de Aedes (Stegomyia) aegypti (Linnaeus, 1762) (Insecta, Diptera, Culicidae) em bromélias, no município do Rio de Janeiro (Rio de Janeiro, Brasil). Biota Neotrop. 8(1):235-237. http:// www.biotaneotropica.org.br/v8n1/pt/fullpaper?bn01508012008+pt.

GREENEY, H.F. 2001. The insects of plant-held waters: a review and bibliography. J. Trop. Ecol. 17:241-260.

KITCHING, R.L. 2000. Food webs and container habitats: the natural history and ecology of phytotelmata. Cambridge University Press, Cambridge.

KITCHING, R.L. 2001. Food webs in phytotelmata: "bottom-up" and "top-down" explanations for community structure. Ann. Rev. Entomol. 46:729-760.

LANE, J. 1953a. Neotropical Culicidae. Vol. 2. Tribe Culicini, Deinocerites, Uranotaenia, Mansonia, Orthopodomyia, Aedeomyia, Aedes, Psorophora, Haemagogus, tribe Sabethini, Trichoprosopon, Wyeomyia, Phoniomyia, Limatus and Sabethes. Editora USP, São Paulo. 
LANE, J. 1953b. Neotropical Culicidae. Vol. 1. Dixinae, Chaoborinae and Culicinae, tribes Anophelini, Toxorhynchitini and Culicini (Genus Culex only). Editora USP, São Paulo.

LOPES, J., ARIAS, J.R. \& CHARLHWOOD, J.D. 1985. Estudos ecológicos de Culicidae (Diptera) silvestres criados em pequenos recipientes de água em mata e em capoeira no Município de Manaus-AM. Cienc. Cul. 37:299-1311.

LOPES, N., NOZAWA, C.\& LINHARES, R.E.C. 2014. Características gerais e epidemiologia dos arbovírus emergentes no Brasil. Rev. Pan-Amaz Saude. 5(3):55-64.

MACHADO-ALLISON, C.E., BARRERA, R.R., DELGADO, L., GÓMEZ-COVA, C. \& NAVARRO, J.C. 1986. Mosquitos (Diptera: Culicidae) e los Fitotelmata de Panaquire, Venezuela. Acta Biol. Venez. 12(2):1-12.

MARCONDES, C.B. \& XIMENES, M.F.F.M. 2016. Zika virus in Brazil and the danger of infestation by Aedes (Stegomyia) mosquitoes. Rev. Soc. Bras. Med Trop. 49(1):4-10.

MARQUES, G.R.A.M \& FORATTINI, O.P. 2008. Culicídeos em bromélias: diversidade de fauna segundo influência antrópica, litoral de São Paulo. Rev. Saúde Pública. 42(6):979-85.

MARQUES, G.R.A.M., SANTOS, R.L.C. \& FORATTINI, O.P. 2001. Aedes albopictus em bromélias de ambiente antrópico no Estado de São Paulo, Brasil. Rev. Saúde Pública. 35:243-248.

MELNYCHUK, M.C.\& SRIVASTAVA, D.S. 2002. Abundance and vertical distribution of a bromeliad-dwelling zygopteran larva, Mecistogaster modesta, in a Costa Rican rainforest (Odonata: Pseudostigmatidae). Int. J. Odonat. 5(1):81-97.

MULLER, G.A. \& MARCONDES, C.B. 2010. First report of oviposition of Aedes albopictus (Skuse, 1894) (Diptera: Culicidae) through holes in bamboos. Ent. News. 121:102-103.

MOCELLIN, M.G., SIMÕES, T.C., NASCIMENTO, T.F.S., TEIXEIRA, M.L.F., LOUNIBOS, L.P. \& OLIVEIRA, R.L. 2009. Bromeliad-inhabiting mosquitoes in an urban botanical garden of dengue endemic Rio de Janeiro - Are bromeliads productive habitats for the invasive vectors Aedes aegypti and Aedes albopictus? Mem. Inst. Oswaldo Cruz. 104:1171-1176.

MOTTA, M.A. \& LOURENÇO-DE-OLIVEIRA, R. 2000. The subgenus Dendromyia Theobald: a review with redescription of four species (Diptera: Culicidae). Mem. Inst. Oswaldo Cruz. 95:649-683.

NAVARRO, J.C., LIRIA, J., PIÑANGO, H. \& BARRERA, R. 2007. Biogeographic area relationships in Venezuela: A Parsimony analysis of Culicidae - Phytotelmata distribution in National Parks. Zootaxa. 1547:1-19.

NEISS, U.G. 2007. Estrutura da comunidade de macroinvertebrados aquáticos associados a Mauritia flexuosa Linnaeus (Arecaceae), fitotelmata, na Amazônia Central, Brasil. Dissertação de Mestrado, Instituto Nacional de Pesquisas da Amazônia, Manaus.

OSPINA-BAUTISTA, F., ESTÉVEZ-VARÓN, J.V., BETANCUR, J. \& REALPEREBOLLEDO, E. 2004. Estructura y composición de la comunidad de macro invertebrados acuáticos asociados a Tillandsia turneri Baker (Bromeliaceae) en un bosque alto andino colombiano. Acta Zool. Mex. 20(1):153-166.
REINERT, J.F. 2009. List of abbreviations for currently valid generic-level taxa in family Culicidae (Diptera). Eur. Mosq. Bull. 27:68-76.

RESENDE, M.C., SILVA, I.M., ELLIS, B.R. \& EIRAS, A.E. 2013. A comparison of larval, ovitrap and MosquiTRAP surveillance for Aedes (Stegomyia) aegypti. Mem. Inst. Oswaldo Cruz. 108(8):1024-1030.

RIBEIRO, J.E.L.S., HOPKINS, M.J.G., VICENTINI, A., SOTHERS, C.A., COSTA, M.A.S., BRITO, J.M., SOUSA, M.A., MARTINS, L.H.P., LOHMANN, L.G., ASSUNÇÃO, P.A.C.L., PEREIRA, E.C., SILVA. C.F., MESQUITA, M.R \& PROCÓPIO, L.C. 1999. Flora da Reserva Ducke: Guia de identificação das plantas vasculares de uma floresta de terra-firme na Amazônia Central. Editora INPA, Manaus.

SANCHEZ, E. \& LIRIA, J. 2009. Relative abundance and temporal variation of macroinvertebrates in a Venezuelan cloud forest habitat. Int. J. Trop. Insect Sci. 29(1):3-10.

SERPA-FILHO, A., FERREIRA, R.L.M., \& BARBOSA, U.C. 2007. Ocorrência de Polypedilum (Tripodura) amataura Bidawid-Kafka, 1996 (Diptera; Chironomidae) em Aquascypha hydrophora (berk.) Reid (Fungi; Stereaceae), com descrição da pupa na Amazônia Central, Brasil. Acta Amazon. 37:151-156.

SOARES, V.A.R.C., RODRIGUES, W.C. \& CABRAL, M.M.O. 2008. Estudo de áreas e depósitos preferenciais de Aedes albopictus (Skuse, 1894) e Aedes aegypti (Linnaeus, 1762) no município de Paracambi - Rio de Janeiro, Brasil. EntomoBrasilis. 1(3):63-68.

SRIVASTAVA, D.S. \& LAWTON, J.H. 1998. Why more productive sites have more species: an experimental test of theory using tree-hole communities. American Naturalist. 116:770-787.

TORREIAS, S.R.S., FERREIRA-KEPPLER, R.L., GODOY, B.S. \& HAMADA, N. 2010. Mosquitoes (Diptera, Culicidae) inhabiting foliar tanks of Guzmania brasiliensis Ule (Bromeliaceae) in central Amazonia, Brazil. Rev. Bras. Entomol. 54(4):618-623.

TORREIAS, S.R.S. \& FERREIRA-KEPPLER, R.L. 2011. Macroinvertebrates inhabiting the tank leaf terrestrial and epiphyte bromeliads at Reserva Adolpho Ducke, Manaus, Amazonas. Braz. Arch. Biol. Technol. 54(6):1193-1202.

YANOVIAK, S.P. 1999. Community structure in water-filled tree holes of Panama: efects of hole height and size. Selbyana. 20:106-115.

YANOVIAK, S.P.; LOUNIBOS, L.P.; WEAVER, S.C. 2006. Land use affects macroinvertebrate community composition in phytotelmata in the Peruvian amazon. Ann. Entomol. Soc. Am. 99(6):1172-1181.

ZAR, J.H. 1996. Biostatistical Analysis. 3 ed. Upper Saddle River. New Jersey: Prentice Hall.

Received: $28 / 10 / 2016$

Revised: 20/06/2017

Accepted: 07/07/2017

Published online: 14/08/2017 